\title{
Predicting Squeezing Potential Along the First 16 Kilometres of the Qomroud Long Tunnel Project in Iran Using Empirical Criteria
}

\author{
A. Shafiei University of Waterloo, Canada \\ M.B. Dusseault University of Waterloo, Canada
}

\begin{abstract}
Central Iran can be described as an arid region which suffers from water shortage and very limited water supply. The Dez-Qomroud tunnel projects will convey water from the adjacent Dez Highlands to a central Iran watershed known as Qomroud in order to satisfy the water needs. In this article, we first highlight the engineering geology, rock mass properties and intact rock properties of the first $16 \mathrm{~km}$ of the Qomroud Long Tunnel (QLT), a portion of the Dez-Qomroud tunnel projects, and then we assess this section for squeezing ground condition potential using available empirical relations and criteria published in the literature. Some mitigation measures are recommended in order to treat the squeezing ground condition in the identified problem bearing sections along the studied tunnel.
\end{abstract}

\section{Introduction}

Prediction of engineering geological hazards such as ground squeezing in design and construction of long tunnel projects is central in any engineering geology and rock mechanics investigations. Yielding of intact rock around a tunnel after excavation leading to large deformations in response to redistribution of in situ stresses which exceed rock strength is known as ground squeezing. Squeezing may cause many problems in tunnelling such as delay in completion and significant increase in the initially estimated cost of the project.

Central Iran can be described as an arid region which suffers from water shortage and very limited water supply. To satisfy the water needs one project will convey water from the adjacent Dez Highlands to a central Iran watershed known as Qomroud. From the initial geological investigations, the main tunnel-axis strata appeared to be schistose rocks such as pelitic schist, calcareous schist, graphitic phyllite and other volcanic rocks. Depth of the tunnel ranges from 20-330 m along the first $16 \mathrm{~km}$ of the QLT tunnel project, measured from inlet/upstream, which is the subject of this study.

In this article, first the mechanism of ground squeezing and proposed empirical criteria for the assessment of this hazard in tunnelling projects is reviewed with some examples of tunnelling through squeezing ground around the globe. Then the engineering geology of the first $16 \mathrm{~km}$ of the QLT tunnel project is described and evaluated for ground squeezing potential using different empirical criteria obtained from the literature. For ease of evaluation of the tunnel, the tunnel path is divided into a number of geomechanical units (GMUs). Then each GMU is assessed for ground squeezing potential using empirical criteria proposed in the literature. Results from this assessment are presented and discussed in this article. Some mitigation measures are proposed along with tunnel design, engineering geological considerations for safe design and construction of this part of the QLT tunnel project.

\section{Background}

Tunnels and other underground works in general can be considered as the most geologically sensitive civil projects undertaken anywhere on the earth. There are numerous examples in the literature from around the world where a tunnel, which is designed and under construction using either a traditional tunnelling method like drill and blast technique or by a Tunnel Boring Machine (TBM), suffers from difficult ground condition such as squeezing ground or other tunnelling engineering geological hazards. Predicting and having a good understanding of the geological hazard before initiating the construction operation will help in choosing a proper solution to solve the problem. However, poor engineering geological investigations or ground 
conditions which are not predicted during the geotechnical investigation stages may lead the project towards more severe construction problems and impose additional costs to the tunnel or underground work project.

Clearly, a well-designed, comprehensive geotechnical study can only examine a negligible portion of the rock mass along a tunnel. The volume of samples taken from boreholes drilled along the tunnel axis is minuscule compared to the volume excavated. The rock volume from an aggressive drilling program compared to the excavated tunnel volume for a medium tunnel size, three $m$ in diameter, is perhaps one in 50,000 . Thus, there is always substantial uncertainty associated with the engineering geology data collected for a tunnel project, even with a comprehensive engineering geology investigation.

Engineering geological problems associated with the nature of geomaterials in a tunnel project include high water inrush, water jet potential in karstic formations, tunnelling through faults or heavily crushed zones, potential of high hydrostatic water pressure in saturated ground, raveling, flowing behaviour (massive watertriggered erosion) in alluvial sections, swelling and ground squeezing in weak rocks. These problems often lead to human life loss or a project shut-down, causing huge unexpected costs for the client. Problem identification well in advance can minimise the risk of unexpected severe engineering geological problems during construction.

In this section, first we will describe the ground squeezing phenomenon with several examples of tunnels around the globe. Then empirical methods, criteria and classifications used to evaluate the squeezing problem in tunnelling and underground works are reviewed.

\subsection{Rock squeezing phenomena}

As stated earlier in this text, redistribution of in situ stresses so they exceed rock strength leads to yielding of the intact rock material around a tunnel after excavation, causing large plastic deformations often referred to as ground squeezing. This tunnelling problem typically occurs during deep tunnelling (depth $>200 \mathrm{~m}$ ) in weak rock such as shales and weak schists where volumetric dilatancy accompanies the process of rock yield and deterioration.

Karl Terzaghi (1950), the founder of modern soil mechanics science, was probably the first scientist who considered the importance of ground behaviour in tunnel construction. Based on his great experience in tunneling with steel supports in soft ground in Europe, he published a classification known as the Tunnelman's Ground Classification System in 1950. It is based on the likely reaction of soil to the tunnelling, which makes possible some level of ground behaviour prediction. He defines the squeezing ground as a phenomenon that ground advances slowly into the tunnel without any signs of fracturing, a time dependent behaviour. The loss of ground around the tunnel and the consequent settlement at the ground surface can be notable in this type of ground behaviour. It should be noted here that Terzaghi's definition of squeezing ground was proposed for soft ground tunnelling however, weak rock at medium depth (highly deformable rock) or medium rock at great depth, behaves plastically and squeeze like a thin non-plastic clay which is described originally by Terzaghi.

The International Society for Rock Mechanics defined the rock squeezing as "Squeezing of rock is the time dependent large deformation which occurs around the tunnel and is essentially associated with creep caused by exceeding a limiting shear stress. Deformation may terminate during construction or continue over a long time period", Barla (1995).

Engineering geological characteristics of the tunnel or underground work, state of in situ stress field (overburden effect), rock mass strength and geomechanical properties, pore pressure and water flow through the rock mass hosting the tunnel are the main controlling factors of squeezing ground behaviour (Barla, 2001). Aydan et al. (1993) proposed a mechanism for squeezing ground behaviour in rock stating that the redistribution of stresses and plastic behaviour of intact rock in an underground opening at great depth after excavation leads to large deformations in the rock mass surrounding the underground opening and squeezing problem. Also, it is indicated that the rock squeezing is a time-dependent behaviour. A number of attempts have been made in the literature to provide us with a better understanding of rock squeezing especially in underground works. Rock squeezing in tunnels, especially in deep tunnels or tunnels in weak rock at medium depth, leads to decrease of the tunnel's cross-section, extra pressure on supports and instability problems and breakage of the supports, in general. 
It should be noted here that the rock squeezing is different from rock burst — which is due to brittle behaviour of hard rocks at great depth, or swelling rock, which is because of an increase in the volume of the ground, usually associated with the absorption of water by swelling clay minerals (plastic behaviour due to presence of plastic clay minerals).

The reader is encouraged to see Terzaghi (1950), Aydan et al. (1993, 1996), Barla (2001) and Kolymbas et al. (2006) for more detailed studies on proposed mechanisms for rock squeezing in tunnelling and underground works.

\subsection{Cases histories}

Rock squeezing problems have been widely reported for a number of tunnel projects around the world causing a range of instability problems, collapse and leading to significant increase in both time and cost of the completion of the projects. These tunnels were designed and constructed using either a conventional tunnelling method or using a TBM. For example, squeezing ground conditions are reported in the Taloun tunnel in Iran (Yassaghi and Salari-Rad, 2005), the Bolu tunnel in Turkey (Dalgic, 2002), and tunnel projects in Germany, Austria, Switzerland, the Furka, Vereina and the Simplon railway tunnels in Switzerland, the Moffat and the Stillwater tunnels in the USA, Tauern and Arlberg tunnels in Austria (Steiner, 1996), the Galgenberg tunnel in Austria (Schubert, 1996), Maneri-Uttarkashi power tunnel in India (Goel et al., 1995), QLT3 and 4 tunnels in Iran (Farrokh et al., 2006), several tunnels in Japan (Aydan et al., 1993, 1996), the Cristina tunnel in Italy, the Gotthard tunnel in Switzerland, the Simplon tunnel, located in the Italian-Swiss border, Trasvase Guadiaro-Majaceite, a TBM driven tunnel in Spain and the Pinglin Highway tunnel in Taiwan (Barla and Pelizza, 2000; Barla, 2001). Also, there are several other case histories of tunnelling through squeezing ground, indicating the importance of considering adverse effects of this engineering geological hazard early in engineering geological and geotechnical investigation.

In one case, mechanised tunnelling using a double-shield hard rock TBM in lots number 3 and 4 of the DezQomroud project, the next half of the QLT tunnel project which is not discussed in the present study, at a depth of 200-650 $\mathrm{m}$ was stopped many times because of severe tunnel convergence and ground squeezing in weak rocks such as schist, phyllite and shale. In one incident, squeezing ground caused 14 months delay in tunnelling operation. Cracking of pre-cast hexagonal concrete segments erected by the double shield TBM was also observed. Excavation of the difficult sections of this tunnel only became possible after several months of ground improvement and mitigation measures such as pre-grouting.

\subsection{Rock squeezing assessment criteria and classifications}

In the tunnelling and engineering geology literature a number of empirical parameters have been proposed to assess ground squeezing potential, especially for deep tunnels and tunnels designed in weak rock masses. In this section some of these proposed criteria and classifications are reviewed.

Perhaps Karl Terzaghi (1946) was the first scientist who accounted rock squeezing as a problem in support design of tunnelling in his proposed classification known as the Tunnelman's Ground Classification System (TGCS) in 1950, based on the likely reaction of soil to the tunnelling, which makes possible some level of ground behaviour prediction. One of the other first attempts to establish a criterion for quantitative assessment of tunnels for rock squeezing problems was made by Muir Wood (1972) where he introduced the concept of the competence factor, $\mathrm{F}_{\mathrm{C}}$, which is the ratio of uniaxial compressive strength of rock to overburden/vertical stresses. For values of $\mathrm{F}_{\mathrm{C}}>2$ the ground is likely to squeeze during tunnelling.

Singh et al. (1992) proposed an empirical criterion for squeezing ground condition prediction based on analysing a number of case histories. Graphical representation of the proposed criterion is shown in Figure 1. The equation of the line is:

$$
\mathrm{H}=350 \mathrm{Q}^{1 / 3}(\mathrm{~m})
$$

where $\mathrm{H}$ is tunnel overburden, $\mathrm{Q}$ is the tunnelling index.

Also, they estimated the rock mass UCS to be:

$$
\mathrm{UCS} \approx 0.7 \gamma \mathrm{Q}^{1 / 3}(\mathrm{MPa})
$$

where $\gamma$ is unit weight of the rock $\left(\mathrm{KN} / \mathrm{m}^{3}\right)$. 
These researchers also concluded that the squeezing ground condition is likely where the overburden is greater than $350 \mathrm{Q}^{1 / 3}(\mathrm{~m})$.

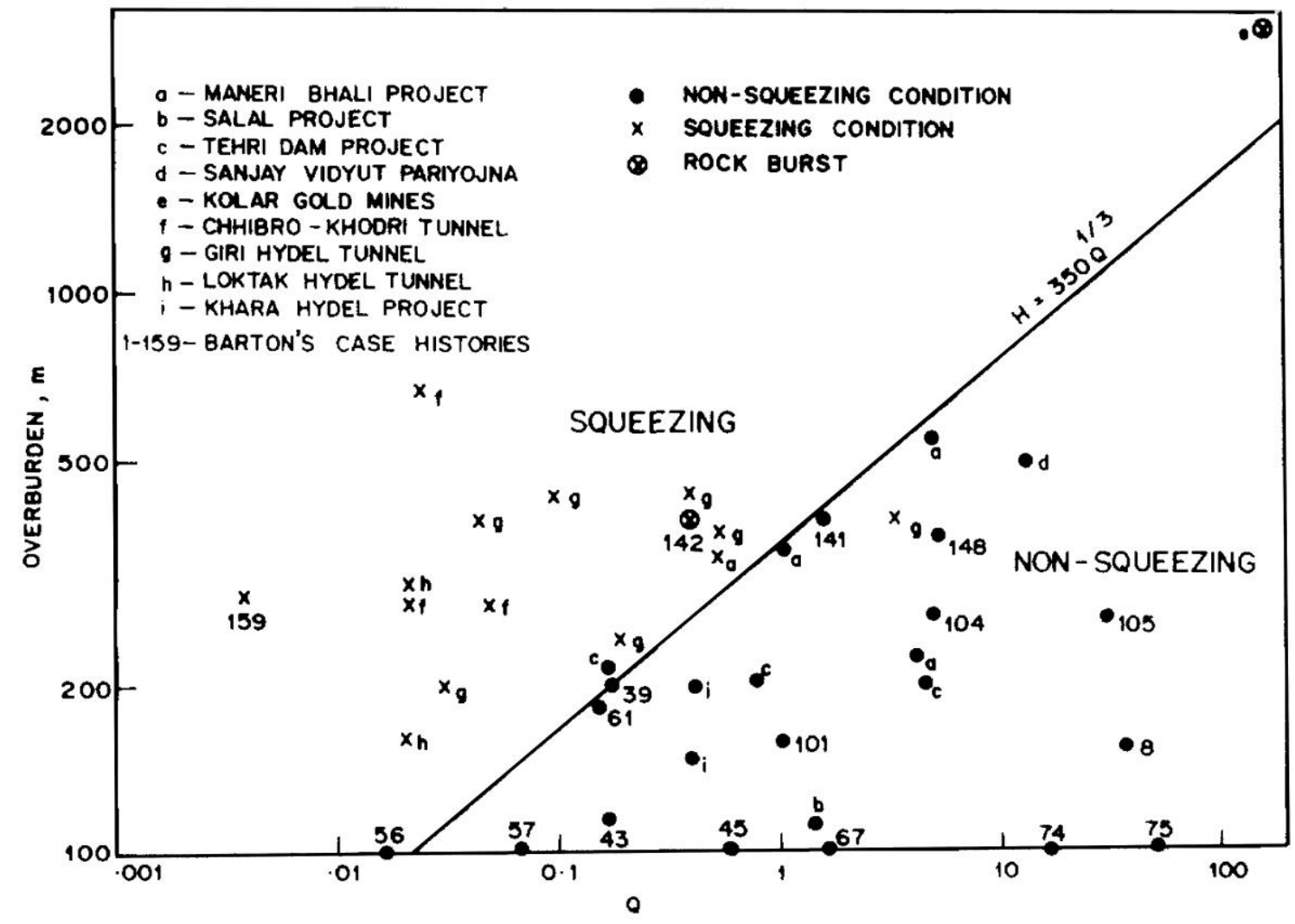

Figure 1 Squeezing ground condition prediction criterion proposed by Sing et al. (1992)

Another empirical method has been proposed by Goel et al. (1995) to predict squeezing ground conditions based on the rock mass number N, which is defined as the 'stress-free' Q tunnelling index:

$$
\mathrm{N}=(\mathrm{Q}) \mathrm{SRF}=1
$$

This approach is implemented in order to avoid uncertainties in determining the correct rating of stress reduction factor (SRF), a parameter in the $\mathrm{Q}$ rock mass classification system and tunnelling index. After analysing parameters like overburden $(\mathrm{H})$, active span $(\mathrm{B})$ and the rock mass number $(\mathrm{N})$ for 99 tunnel sections, as shown in Figure 2, Singh and Geol (1999) proposed a log-log diagram to predict squeezing ground conditions, where:

$$
\mathrm{H}>\left(275 \mathrm{~N}^{0.33}\right) \mathrm{B}^{-1}(\mathrm{~m})
$$

can be considered as squeezing conditions.

They also proposed a classification for the degree of the ground squeezing problem for the abovementioned empirical method based on tunnel convergence.

- Mild squeezing: convergence of $1-3 \%$ of diameter D.

- Moderate squeezing: convergence of 3-5\% of D.

- High squeezing: convergence of $>5 \%$ of $\mathrm{D}$.

After analysing a number of tunnel projects in Japan, Aydan et al. (1993) proposed a semi-empirical method for predicting squeezing ground conditions based on the relation between intact rock strength $\left(\sigma_{\mathrm{ci}}\right)$ and overburden weight $(\gamma \mathrm{H})$, Figure 3. They assumed that the intact rock strength and the rock mass strength are equal. Squeezing ground condition is likely to occur when $\alpha=\sigma_{\mathrm{c} i} / \gamma \mathrm{H}$ is less than 2.0. 


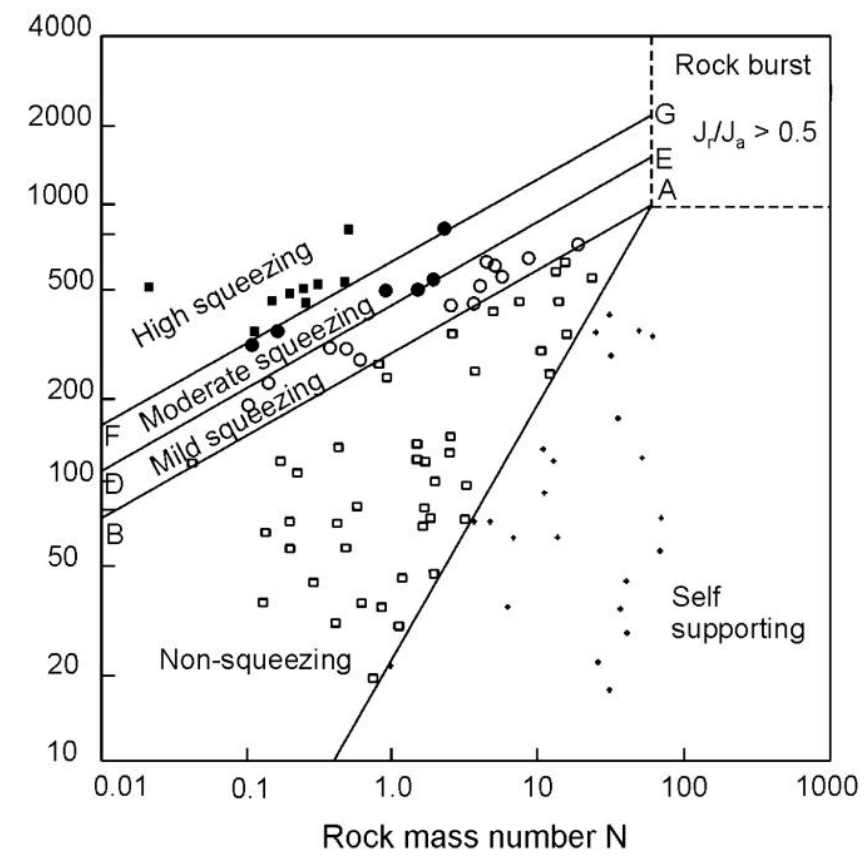

Figure 2 Squeezing ground condition prediction method proposed by Singh and Goel (1999)

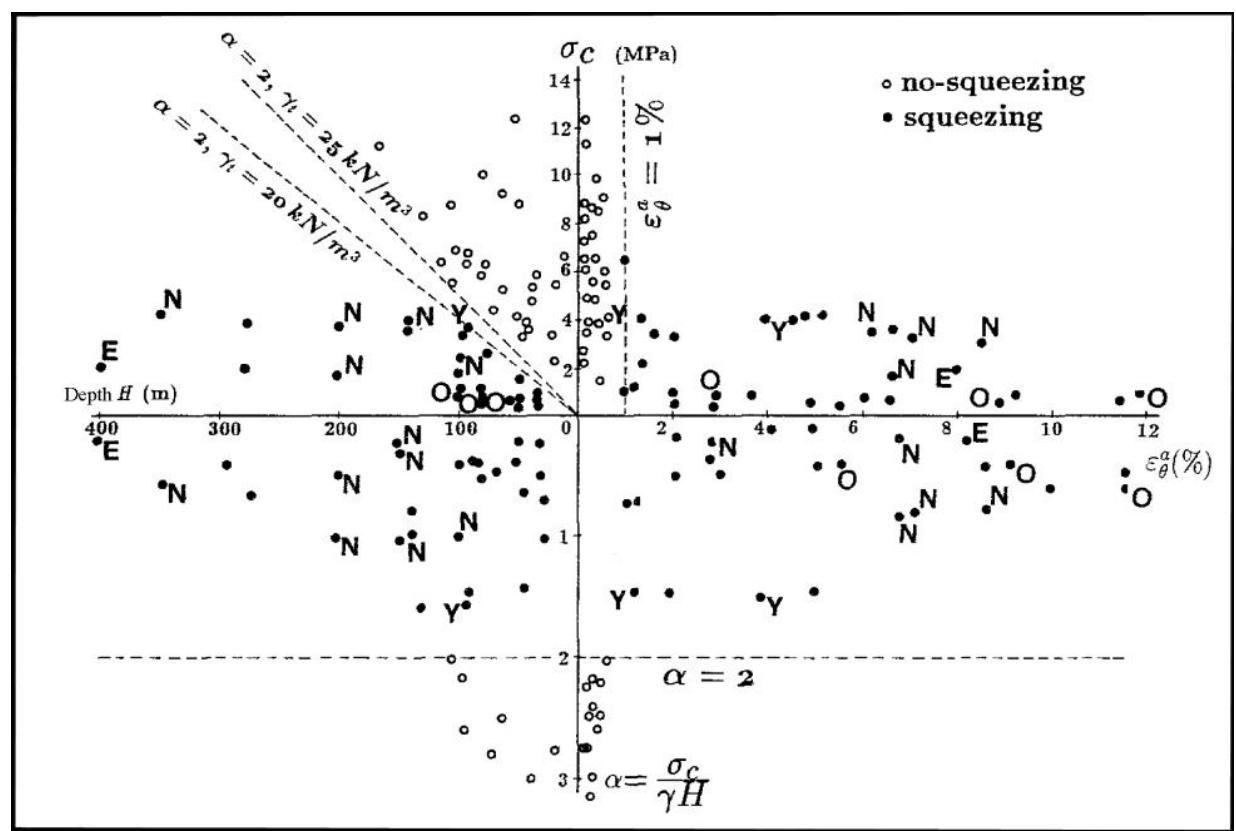

Figure 3 Proposed method for prediction of squeezing ground condition by Aydan et al. (1993)

Hoek and Marinos (2000) proposed using the ratio of uniaxial compressive strength of the rock mass to the in situ stress as a criterion for prediction of squeezing ground potential as shown in Figure 4. The principle of their proposed method is similar to the proposed method by Aydan et al. (1993).

Hoek (2001) proposed a relation based in part on studies of an axi-symmetric finite element numerical model:

$$
\varepsilon_{t}(\%)=0.15\left(1-p_{i} / p_{o}\right) \frac{\sigma_{c m}}{p_{0}}-\left(\left(3 p_{i} / p_{o}+1\right)\right) /\left(\left(3.8 p_{i} / p_{o}\right)+0.54\right)
$$

where $\varepsilon_{\mathrm{t}}$ is the tunnel strain (\%), $\mathrm{p}_{\mathrm{o}}(\mathrm{MPa})$ is the in situ stress and the $\mathrm{p}_{\mathrm{i}}$ is the support pressure (MPa). 


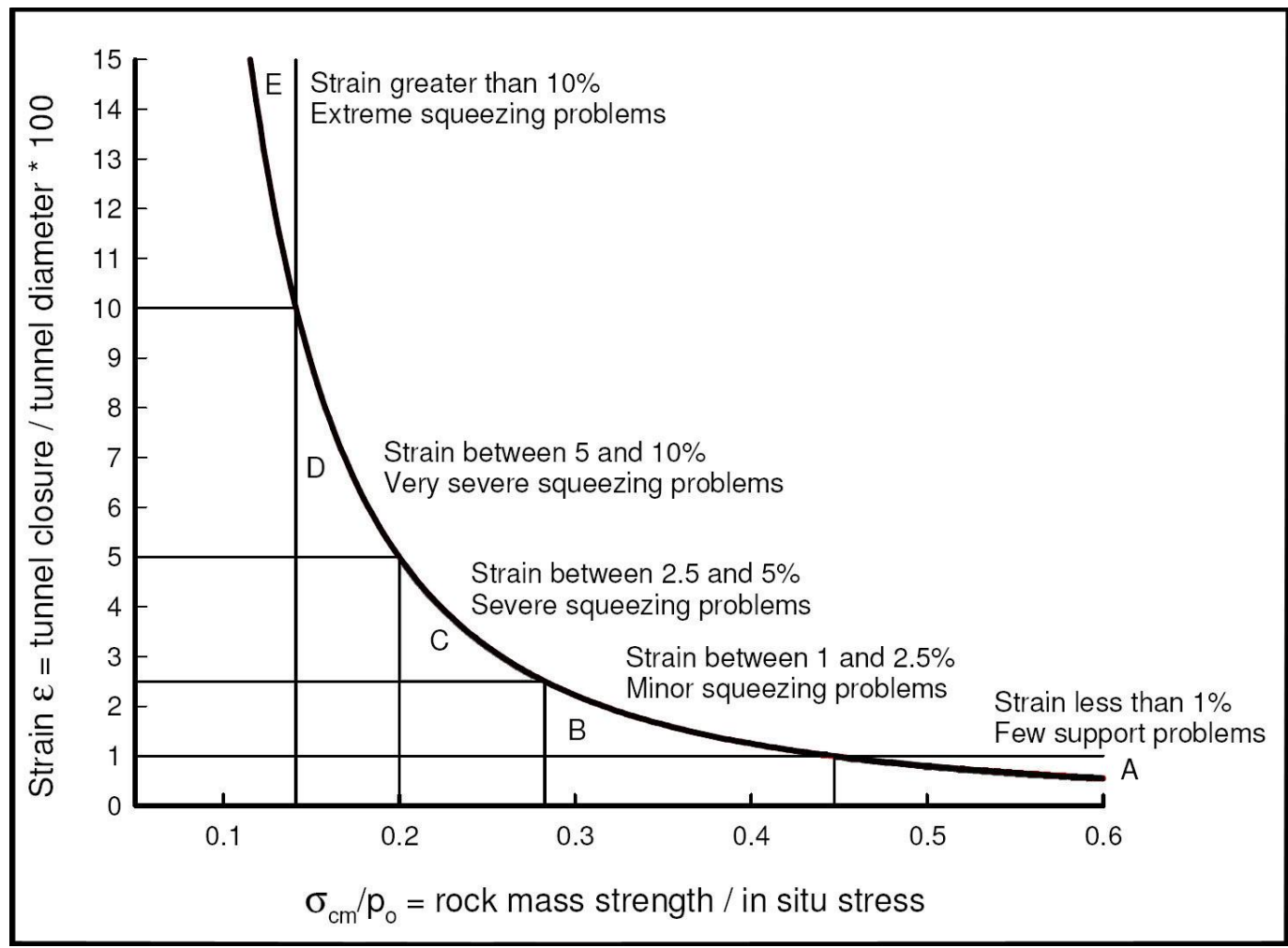

Figure 4 Proposed method for prediction of squeezing ground condition by Hoek and Marinos (2000)

Many other empirical, semi-empirical and numerical methods proposed for the purpose of ground squeezing prediction are reported in the literature. Reviewing all of these criteria is out of the scope of this article. For a more comprehensive review and discussion of such parameters see Barla (2001).

\subsection{Mitigation measures and design considerations}

Rock squeezing has been responsible for a range of instability problems such as collapse, reduction of the cross-section of the tunnel and extra pressure on lining, leading to a significant increase in both the time and the cost of projects. Over the last few decades, a number of mitigation measures have been proposed and implemented to treat the squeezing problem in tunnelling industry in both mechanised and conventional methods. In this section a few of these techniques are discussed briefly. During conventional tunnelling in a squeezing ground, implementation of a carefully designed and operated sequential excavation can control the squeezing problem. Support installation is necessary right after full face excavation if implemented in a squeezing ground. A range of problems during mechanised tunnelling in squeezing ground may occur such as face instability, gripping problems for gripper machines, maintaining sufficient thrust for the advancement of machines and some other problems. Obviously, here the tunnel divergence is the most important issue, much more severe for the shielded machines, and there is not a single solution for this problem. Nevertheless, using ground improvement techniques (i.e. grouting) in order to control the ground convergence and providing a solid media for the TBM advancement may help as this is experienced in QLT 3-4 project in Iran. However, this will cause some delay in completion of the project, will impose some extra expenses and will lower the safety and lower the service life of the tunnel. For more detailed and comprehensive discussions on this topic the reader is referred to Kovari and Staus (1996), Barla and Pelizza (2000) and Barla (2001).

\section{The Qomroud long tunnel project}

Central Iran can be considered as an arid area with very limited water supply. Providing enough water to this area is a great challenge for the Iranian water supply industry. To help address the water needs, a project known as the Dez-Qomroud will convey water from the adjacent Dez Highlands to the central Iran water- 
shed; it involves four tunnels (total length of $54 \mathrm{~km}$ ), three small dams and a large dam. The longest tunnel in the Dez-Qomroud projects, QLT, has a length of nearly $36 \mathrm{~km}$. The QLT, inlet front, is located $22 \mathrm{~km}$ south of Aligoudarz-Isfahan road, accessed by the Shoul-Abad road from Aligoudarz town, Lorestan Province, west central Iran (Figure 5). In this section, engineering geology of the first $16 \mathrm{~km}$ of the QLT tunnel project is described.

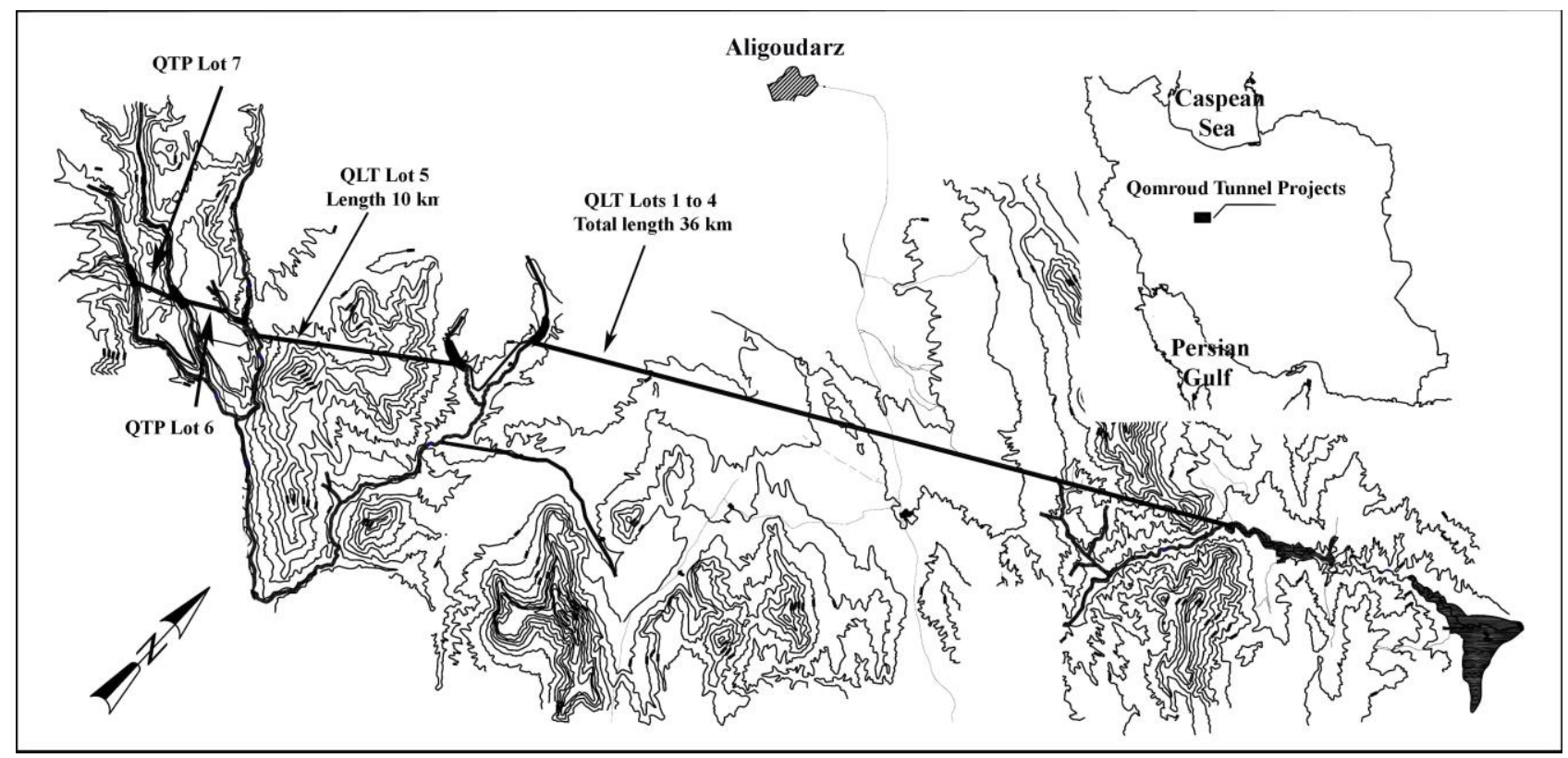

\section{Figure 5 Geographical location and layout of the Qomroud water transfer project known as QLT} tunnel project in Iran

From the initial stage of engineering geology studies, the main strata along the first $16 \mathrm{~km}$ of the QLT tunnel appeared to be schistose rocks such as pelitic schist, calcareous schist, and graphitic phyllite, alternating with interlayers of meta-dolomite and meta-quartzite and some other volcanic rocks. Construction of the QLT began in 2001 using drill-and-blast methods. After $919 \mathrm{~m}$ of uneventful progress, a huge mass of saturated silty clay sank into the tunnel, creating a sinkhole at the ground surface, $52 \mathrm{~m}$ above the crown. The presence of saturated alluvial materials along the axis had not been foreseen, or at the very least its effect had been underestimated. To clarify the geology model and implement a proper construction method, a complementary engineering geological study was designed and conducted. Results obtained from the new engineering geological studies led to a substantial change in the geological model of the tunnel compared with results from earlier exploration stage. Drill-and-blast techniques were deemed to be no longer suitable for continued construction, and the tunnel was abandoned during the winter of 2004 to gather required data and make decisions. It should be noted here that until writing these rows $15 \mathrm{~km}$ of the QLT tunnel is excavated from the other front, outlet or downstream, using a double shield TBM starting from January $2004,260 \mathrm{~m} /$ month, under intense squeezing conditions.

Stocklin (1968) defined five major geological zones in Iran, based on geological, structural and sedimentological features. The QLT is situated in the southern part of the Sanandaj-Sirjan zone (Figure 6) where the trend of structure is NW-SE, similar to the general trend of the Sanandaj-Sirjan zone and the Zagros tectonic belt. Regional metamorphism grades vary from medium to high grade; the metamorphic rocks encountered in the project area are mainly composed of metapelitic rock species such as graphite schist, chlorite schist, phyllite and meta-basic rock species such as: meta-andesite, meta-rhyodacite, amphibolite, and metamorphosed carbonate rocks like meta-dolomite and meta-dolomitic limestone. Most of the lithostratigraphic units and tectonic structures in the QLT project area are covered by Quaternary deposits, especially alluvial plain deposits composed of fine- to medium-grained alluvium with inter-beds of immature conglomerate strata. Alluvium depth in some points in the study area exceeds $300 \mathrm{~m}$. In the study area, there is also clear evidence of very high tectonic activity in the Sanandaj-Sirjan zone, as well as an active and complex ground water flow system. 


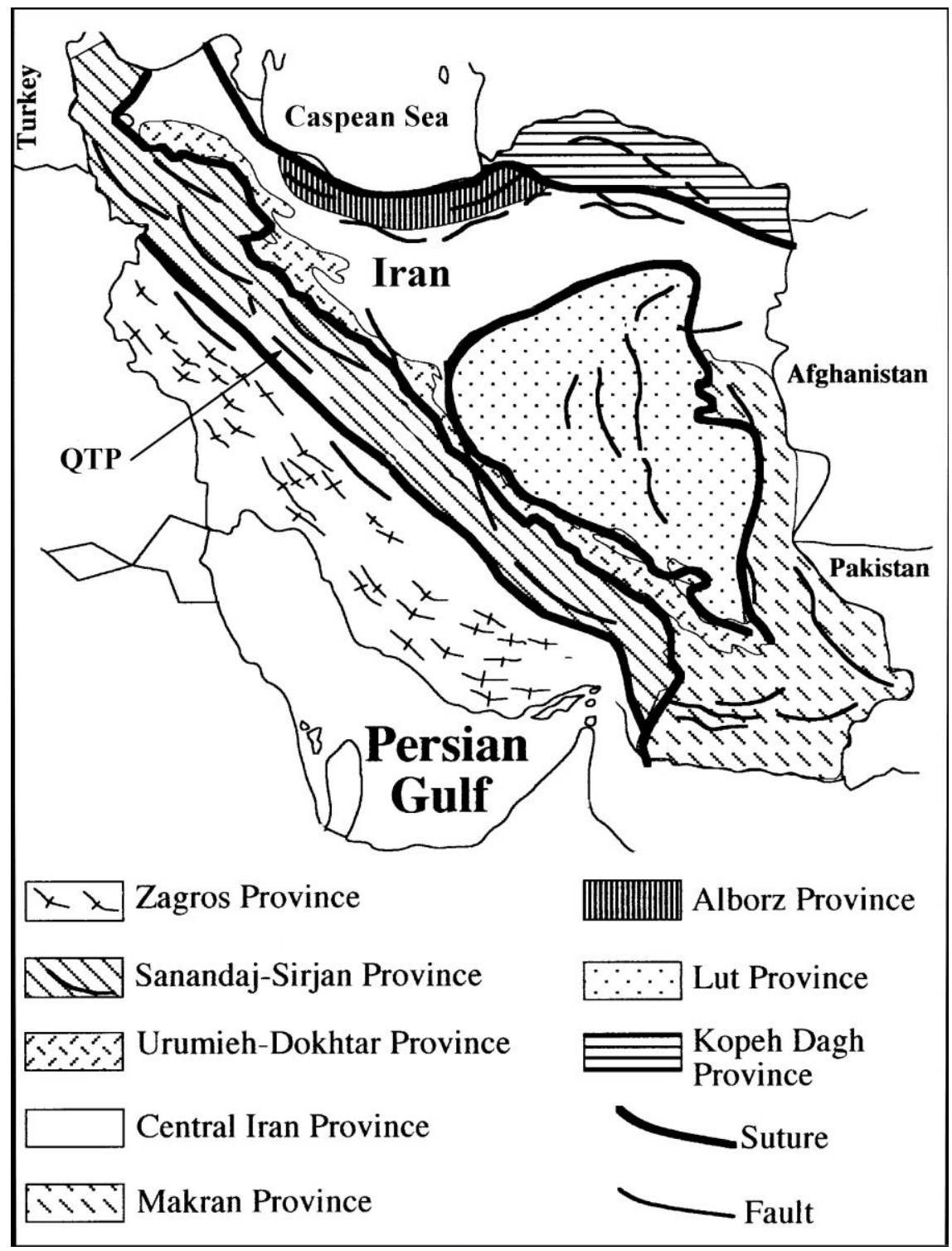

Figure 6 Study area in the Sanandaj-Sirjan zone

Based on preliminary geological and geotechnical investigations along the tunnel path, the main geological strata through which QLT will pass are medium to strong rock species such as meta-andesite, meta-dolomite, meta-quartzite and different kinds of phyllite, and different types of schist. A geological map and a longitudinal profile along the QLT route based on Phases I and II engineering geological and geotechnical studies is shown in Figure 6. Maximum and minimum overburden depth along QLT is 20 and $330 \mathrm{~m}$, respectively.

The construction of the first lot of the QLT tunnel (QLT1), from the inlet, began in June 2000. It was contractually anticipated that construction of QLT1 would be completed in 2005. The tunnel was designed initially to convey $23 \mathrm{~cm} / \mathrm{sec}$ of water. The tunnel section has a downward slope of 0.0013 , and has a curvedwall gate arch shape; the curved wall is $2.15 \mathrm{~m}$ high with a radius of $2.35 \mathrm{~m}$, and the excavation area is about $20 \mathrm{~m}^{2}$. The excavation sequence and support systems were designed based on the Austrian Standard ONORM B 2203 (1994), implementing the concept of the New Austrian Tunnelling Method (NATM). Drilland-blast was adopted as the excavation method. A combination of post-excavation support systems and reinforcements (shotcrete, wire-mesh, rock bolts, lattice girder beams) were used in different segments of the QLT1 route. Construction of QLT1 started from three faces simultaneously, including the main tunnel and access tunnels ${ }^{\# 1}$ and ${ }^{\#}$. Severe instability problems were encountered at all faces. The main tunnel was excavated in meta-andesite until $0+360 \mathrm{~km}$ chainage and in schist from chainage $0+360$ to $0+919 \mathrm{~km}$. 

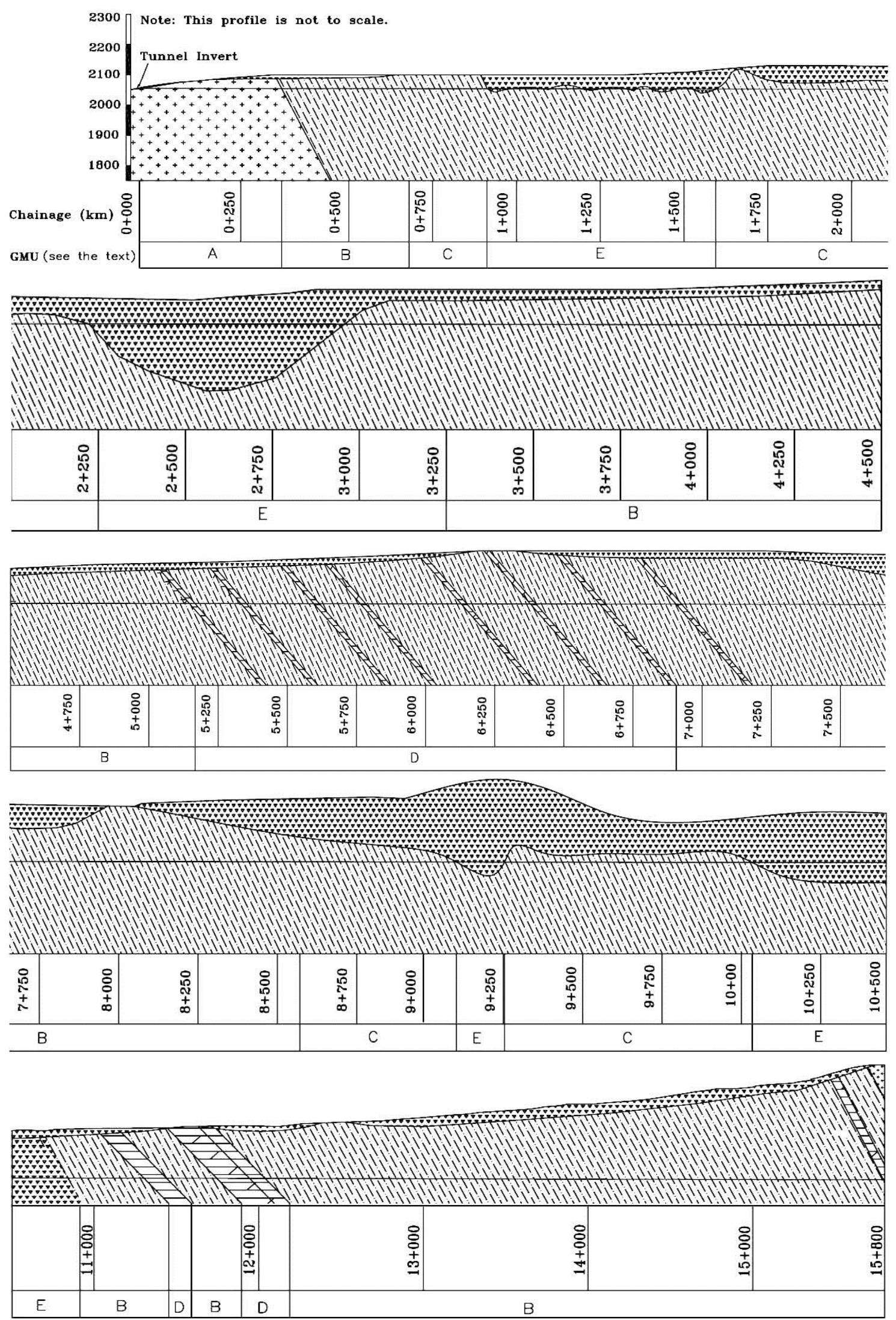

Figure 7 Modified longitudinal geological profile along the first $16 \mathrm{~km}$ of the QLT1 tunnel project 
During excavation of the main tunnel, medium to hard rocks became progressively replaced by weak and crushed rocks of different types; finally, at 0+919 km chainage, in September 2001, a large crown collapse led to flow of $1,500 \mathrm{~m}^{3}$ of water and fine-grained soil slurry into the tunnel. Collapse created a large cylindrical hollow area, a sinkhole $52 \mathrm{~m}$ deep and $35 \mathrm{~m}^{2}$. This face was closed after the incident; no fatalities and only a few injuries resulted from the collapse and influx.

Access tunnel ${ }^{\#} 1$, known as adit ${ }^{\#} 1$, with a length of $610 \mathrm{~m}(430 \mathrm{~m}$ in saturated alluvium, $180 \mathrm{~m}$ in heavily crushed schist), was anticipated to reach the main tunnel at $03+535 \mathrm{~km}$ chainage. The cross-section was almost identical to the main tunnel section. Tunnel construction in saturated fine-grained alluvium below the water table was quite challenging, especially with a traditional tunnelling method using an excavator. Lack of experience and proper tunnelling equipment, contractual issues, and, more importantly, social problems in the area led to permanent abandonment of adit " 1 in March 2004.

The main challenge was the slow rate of advancement $-<1 \mathrm{~m} / \mathrm{d}$, tunnel roof instability and occasional full roof collapse. In rare occasions, cave-ins of nearly $200 \mathrm{~m}^{3}$ at the roof of the tunnel took place. Preliminary support for adit ${ }^{\#} 1$ consisted of steel sets (IPE 14) with spacing of $0.30-1.0 \mathrm{~m}$, two layers of $6 \mathrm{~mm}$ wire mesh, and two layers of dry-mix shotcrete with a total thickness of $10-20 \mathrm{~cm}$. Contractual issues did not allow the contractor to use pre-grouting techniques such as fore-poling. The contractor had to use the contractually stipulated method of traditional machine excavation despite encountering engineering geological problems and therefore inefficiencies with the adopted excavation technique. Also, social problems at many stages of construction shut down the site and dewatering was interrupted, leading to flooding of the tunnel and equipments, and causing huge instabilities.

The general characteristics of adit ${ }^{\#} 2$ are similar to adit ${ }^{\#} 1$; its length is $01+460 \mathrm{~km}$ and it intersects with the main tunnel at $07+180 \mathrm{~km}$ chainage. This site faced the same problems as the others; after several floods and stability problems, adit \#2 was abandoned permanently in June 2003.

The construction of the second lot of the QLT known as QLT2 began in 2001. Because of the dead end of this lot from both ends, two access tunnels, adit \#3 (Moqanak which intersects the main tunnel in the chainage $11+600 \mathrm{~km}$ with length of $1600 \mathrm{~m}$ and a downward slope of 8-10\%) and adit ${ }^{\#} 4$ (Askaran which intersects the main tunnel in the chainage $14+000 \mathrm{~km}$ with a length of $1800 \mathrm{~m}$ and a downward slope of 8-10\%) were designed in order to reach the main tunnel and make possible its excavation using the drill-andblast method. The general characteristics of these adits are similar to the adits ${ }^{2} 2$ and ${ }^{\#} 3$. These tunnels excavated through medium to hard strata are mainly composed of schist, limestone and meta-dolomite. A water jet occurred in the chainage of $1+050 \mathrm{~km}$ in the adit \#3 with the discharge quantity of $1620 \mathrm{~L} / \mathrm{sec}$ and a calculated water pressure of $10 \mathrm{MPa}$ during excavation in the meta-dolomite unit. High pressure water ingress into the tunnel lasted 40 days but advancement became possible after six months of a massive impermeation grouting operation. Both of these adits were completed in 2004, over two years behind schedule. Due to some unpredicted geological, and therefore operational problems, the construction of the QLT2 stopped in January 2005.

Closing the QLT1 and 2 projects has led to controversial and difficult discussions within the authorities and the tunnelling industry in Iran, mainly because the overall feasibility of the Dez-Qomroud water conveyance project came under question. Also, at that time, it was the first experience in Iran for the design and construction of such a long tunnel project. The message from the engineering geology of the tunnel route was clear: the ground behaviour was not well understood or predictable. Lack of sufficient and efficient engineering geological investigations, inflexible Iranian tunnelling contracts which neglected the effect of changing geology on operations and underestimation of the tunnelling difficulties in mixed geology or within the saturated fine-grained loose media led to abandonment of the QLT1 and 2. Less than one per cent of the value of the initial contract was spent on engineering geological and geotechnical investigations. This ratio should be at least two to four per cent for such a tremendous and important civil project through difficult ground.

Recently, a complementary engineering geological and geophysical investigation program was designed and carried out in order to remove doubts about the geological profile of QLT1 and 2. This plan consisted of drilling 12 new boreholes and conducting a geophysical survey using geo-electrical methods along the QLT1 and 2 routes. The modified longitudinal geological profile is presented in Figure 7. The new engineering geological and geotechnical findings replaced medium to hard rocks in the primary geological-geotechnical 
profiles by weak to medium rocks, with almost $1.40 \mathrm{~km}$ of fine-grained saturated soils 'appearing' along the QLT1 and 2 routes. Results of the new geological investigations led to a revisitation of rock mass characterisation results along the QLT1 and 2 tunnel routes and identification and definition of new sets of GMUs.

A group of rock types in a rock mass with similar litho-stratigraphical and structural features may be defined as a single GMU. For engineering analysis, each rock mass must be divided into a tractable number of GMUs in order to ease the problem of rock mass characterisation. Each GMU is distinct from other GMUs in a rock mass (e.g. through layering, fault separation or litho-mechanical contrasts) and has its own geomechanical characteristics.

Data obtained from complementary geotechnical investigations changed the predicted geology of the QLT1 tunnel as follows:

- Chainage 0+000 to 0+356 km. Dark green andesite to andesi-basalt (already excavated using drill-and-blast technique).

- Chainage $0+356$ to $0+700 \mathrm{~km}$. A slightly weathered green to grey schist with inter-beds of meta-dolomitic limestone (already excavated with the drill-and-blast method).

- Chainage $0+700$ to $0+919 \mathrm{~km}$. A green to grey weathered and crushed schist (already excavated with drill-and-blast method).

- Chainage 0+919 to $1+600 \mathrm{~km}$. Alluvial materials (soft ground) fully saturated, GC, CL-ML materials of Quaternary age.

- Chainage $1+600$ to $3+250 \mathrm{~km}$. Fully saturated alluvial materials (soft ground) such as GC and CL-ML materials of Quaternary age.

- Chainage $3+250$ to $5+200 \mathrm{~km}$. A slightly weathered green to grey schist with inter-beds of meta-dolomitic limestone.

- Chainage 5+200 to 7+000 km. Meta-dolomite and meta-quartzite with inter-beds of compact schist.

- Chainage 7+000 to $8+600 \mathrm{~km}$. A slightly weathered green to grey schist with inter-beds of meta-dolomitic limestone.

- Chainage $8+600$ to $9+100 \mathrm{~km}$. A green to grey weathered and crushed schist.

- Chainage 9+100 to 9+250 km. Fully saturated alluvial materials (soft ground) such as GC and CL-ML materials of Quaternary age.

- Chainage 9+250 to 9+900 km. A green to grey weathered and crushed schist.

- Chainage 9+900 to 10+800 km. Fully saturated alluvial materials (soft ground) such as GC and CL-ML materials of Quaternary age.

- Chainage $10+800$ to $11+500 \mathrm{~km}$. A slightly weathered green to grey schist with inter-beds of meta-dolomitic limestone.

- Chainage 11+500 to 11+600 km. Meta-dolomite and meta-quartzite with inter-beds of compact schist.

- Chainage $11+600$ to $11+800 \mathrm{~km}$. A slightly weathered green to grey schist with inter-beds of meta-dolomitic limestone.

- Chainage $11+800$ to $12+200 \mathrm{~km}$. Meta-dolomite and meta-quartzite with inter-beds of compact schist.

- Chainage $12+200$ to $16+000 \mathrm{~km}$. A slightly weathered green to grey schist with inter-beds of meta-dolomitic limestone.

Based on the current study, five major GMUs were identified along the QLT1 tunnel route, assigned letters from A to E. 
- Unit A is composed of dark green competent andesite to andesi-basalt which is already excavated using the drill-and-blast technique).

- Unit B is composed of a slightly weathered green to grey schist with inter-beds of meta-dolomitic limestone.

- Unit $\mathrm{C}$ is composed of green to grey weathered and crushed schist.

- Unit D is mostly composed of meta-dolomite and meta-quartzite with inter-beds of compact schist.

- Unit E is composed of fully saturated alluvial materials such as GC and CL-ML of Quaternary age.

Detailed laboratory studies were carried out on core samples of NX-size, $54.7 \mathrm{~mm}$, taken from the drilled boreholes. Different geomechanical parameters were determined according to the ASTM standards and the ISRM (1981) suggested methods. A summary of the results is presented in Table 1. Engineering properties of the soil specimens were determined based on ASTM Standards but results are not shown in this article.

Rock mass classifications have been proposed using geological and geotechnical data for the four distinct rock-like GMUs (A to D) along the QLT1 and 2 tunnel routes. The rock mass rating (RMR) (Bieniawski, 1976, 1989), Q-system (Barton et al., 1974), GSI (Hoek et al., 1995), RQD (Deere et al., 1967) and rock mass index (RMi) (Palmstrøm, 1996) assessment method were applied to the rock masses defined along the QLT route. Results from application of different rock mass classification systems and their description for the purpose of rock mass classification and appraisal of the different GMUs along the QLT tunnel route is summarised in Table 2. For a comprehensive rock mass and intact rock characterisation of the strata along the first $10+500 \mathrm{~km}$ of the QLT, see the article by Shafiei et al. (2008).

\section{Discussion}

The first $16 \mathrm{~km}$ of the QLT tunnel: QLT1 and 2 sections of the Dez-Qomroud water conveyance project will pass through very different geological strata from the strength and stiffness points of view, ranging from soft saturated soils to medium and hard rocks. The QLT is situated in the most tectonically active zone in Iran, the Sanandaj-Sirjan zone, and has experienced several metamorphism and magmatism events in its geological history. The geologic history substantially affected the engineering geological properties and mechanical behaviour of the strata zone. The drill-and-blast construction techniques that were chosen for QLT1 and 2 were based on inadequate preliminary engineering geological and geotechnical investigations results.

Unpredicted and therefore unexpected geological conditions, combined with the inflexible nature of tunnel contracts in Iran, led to the abandonment of QLT1 and 2 advances at all the faces from 2004 till now. This caused severe social problems because of a local high unemployment rate and land usage problems in the area. The Dez-Qomroud water transfer project was delayed with a direct loss of about $\$ 40$ million.

Table 1 Physical and geomechanical properties of the rock materials along the QLT1 tunnel route

\begin{tabular}{|c|c|c|c|c|c|c|c|c|c|}
\hline \multirow{2}{*}{ Material } & \multicolumn{2}{|c|}{$\rho\left(\mathrm{g} / \mathrm{cm}^{3}\right)$} & \multirow{2}{*}{$\mathrm{W}_{\mathrm{a}} \%$} & \multirow{2}{*}{$\mathrm{n}$} & \multirow{2}{*}{$v$} & \multirow{2}{*}{$\mathrm{E}(\mathrm{GPa})$} & \multirow{2}{*}{$\begin{array}{c}\sigma_{\mathrm{c}} \\
(\mathrm{MPa})\end{array}$} & \multirow{2}{*}{$\begin{array}{c}\mathrm{V}_{\mathrm{s}} \\
(\mathrm{km} / \mathrm{s})\end{array}$} & \multirow{2}{*}{$\begin{array}{c}\mathrm{V}_{\mathrm{p}} \\
(\mathrm{km} / \mathrm{s})\end{array}$} \\
\hline & $\mathrm{s}$ & $\mathrm{d}$ & & & & & & & \\
\hline Schist & 2.45 & 2.40 & - & - & - & $2-12$ & $11-33$ & $\begin{array}{l}1.73- \\
2.35\end{array}$ & $\begin{array}{c}3.20- \\
5.60\end{array}$ \\
\hline $\begin{array}{l}\text { Meta-dolomitic } \\
\text { limestone }\end{array}$ & 2.76 & 2.74 & $0.7-1$ & 2.1 & 0.25 & $12-22$ & 55 & 3 & 4.73 \\
\hline Meta-quartzite & 2.79 & 2.77 & $0.6-9$ & 1.79 & 0.17 & $19-35$ & 83 & 3.14 & 4.98 \\
\hline Meta-limestone & $\begin{array}{c}2.68- \\
2.90\end{array}$ & $\begin{array}{c}2.10- \\
2.69\end{array}$ & - & $\begin{array}{c}0.55- \\
2.06\end{array}$ & - & $18-27$ & $58-100$ & $3.0-3.64$ & $\begin{array}{c}5.18- \\
5.90\end{array}$ \\
\hline $\begin{array}{l}\text { Meta-andesite, } \\
\text { Meta-andesi- } \\
\text { basalt }\end{array}$ & 2.70 & 2.65 & - & - & 0.22 & $15-20$ & $60-70$ & $\begin{array}{c}3.60- \\
3.80\end{array}$ & $\begin{array}{c}4.20- \\
4.50\end{array}$ \\
\hline
\end{tabular}


Table 2 Summary of rock mass classification values for the different GMU along the QLT1 and 2 tunnel routes, first $16 \mathrm{~km}$ of the QLT tunnel, and their description

\begin{tabular}{|c|c|c|c|c|c|c|c|c|}
\hline \multirow{3}{*}{$\begin{array}{c}\text { Rock Mass } \\
\text { Classification } \\
\text { System }\end{array}$} & \multicolumn{8}{|c|}{ GMU Along the QLT1 Tunnel Route } \\
\hline & \multicolumn{2}{|r|}{ A } & \multicolumn{2}{|r|}{ B } & \multicolumn{2}{|r|}{$\mathrm{C}$} & \multicolumn{2}{|r|}{$\mathrm{D}$} \\
\hline & Value & Description & Value & Description & Value & Description & Value & Description \\
\hline RMR & $73-86$ & $\begin{array}{l}\text { Good to very } \\
\text { good rock }\end{array}$ & $31-49$ & $\begin{array}{l}\text { Poor to fair } \\
\text { rock }\end{array}$ & $23-35$ & Poor rock & $68-75$ & Good rock \\
\hline Q & $\begin{array}{c}21.11- \\
27.50\end{array}$ & Good & $\begin{array}{c}5.75- \\
9.70\end{array}$ & Fair & $\begin{array}{c}1.39- \\
1.42\end{array}$ & $\begin{array}{l}\text { Poor to very } \\
\text { poor }\end{array}$ & $\begin{array}{c}15.16- \\
19.66\end{array}$ & Good \\
\hline $\mathrm{RMi}$ & $\begin{array}{c}22.31- \\
43.27\end{array}$ & Very strong & $\begin{array}{c}0.53- \\
4.65\end{array}$ & $\begin{array}{l}\text { Medium to } \\
\text { strong }\end{array}$ & $\begin{array}{c}0.031- \\
0.048\end{array}$ & $\begin{array}{l}\text { Weak to } \\
\text { medium }\end{array}$ & $\begin{array}{l}9.76- \\
24.84\end{array}$ & $\begin{array}{l}\text { Strong to very } \\
\text { strong }\end{array}$ \\
\hline RQD & $90-100$ & Excellent & $45-50$ & Poor & $15-20$ & Very poor & $60-70$ & Fair \\
\hline GSI & $62-80$ & $\begin{array}{c}\text { Blocky/good } \\
\text { to blocky/very } \\
\text { good (B/G to } \\
\text { B/VG) }\end{array}$ & $28-43$ & $\begin{array}{c}\text { Very } \\
\text { blocky/good to } \\
\text { very blocky/ } \\
\text { very good } \\
\text { (VB/G to } \\
\text { VB/VG) }\end{array}$ & $15-32$ & $\begin{array}{c}\text { Disintegrated/ } \\
\text { very poor to } \\
\text { disintegrated/ } \\
\text { poor and } \\
\text { blocky or } \\
\text { disturbed/very } \\
\text { poor to blocky } \\
\text { or disturbed/ } \\
\text { poor (D/vP to } \\
\mathrm{D} / \mathrm{P} \text { and } \\
\mathrm{BD} / \mathrm{VP} \text { to } \\
\mathrm{BD} / \mathrm{P} \text { ) }\end{array}$ & $55-65$ & $\begin{array}{l}\text { Very blocky/ } \\
\text { good to very } \\
\text { blocky/very } \\
\text { good (VB/G to } \\
\text { VB/VG) }\end{array}$ \\
\hline
\end{tabular}

Eventually, complementary engineering geological and geophysical investigations were carried out along QLT1 and 2 to reduce uncertainty in the engineering geological profile. This should lead to better understanding of geo-material behaviour of tunnel strata, allowing the selection of an optimum construction method to continue. In this section, the potential for squeezing ground will be determined and discussed for each GMU along the most critical sections in first $16 \mathrm{~km}$ of the QLT tunnel. Furthermore, a summary of the calculations for determining squeezing ground conditions using some of the proposed empirical relations and criteria in the literature for the examined sections is presented in Table 3. The most critical section is selected in each GMU. The calculations are repeated for different chainages, and sections with squeezing potential can be mapped and presented on the engineering geological profile of the first $16 \mathrm{~km}$ of the QLT.

\section{Unit A}

This unit extends from chainage $0+000$ to $0+356 \mathrm{~km}$ and is composed of dark green competent andesite to andesi-basalt. Unit A was already excavated using drill-and-blast techniques without any serious problem during the initial tunnelling operation. Because of the competent nature of the rock and the good quality of the rock mass this section was not susceptible to the squeezing ground condition.

\section{Unit B}

The QLT1 will pass through this unit in chainages $0+356$ to $0+700 \mathrm{~km}, 3+250$ to $5+200 \mathrm{~km}, 7+000$ to $8+600 \mathrm{~km}, 10+800$ to $11+500 \mathrm{~km}, 11+600$ to $11+800 \mathrm{~km}$ and $12+200$ to $16+000 \mathrm{~km}$. These sections are composed of a slightly weathered, green to grey schist with inter-beds of meta-dolomitic limestone. Chainage $0+356$ to $0+700 \mathrm{~km}$ has already been excavated without problems except for a few minor cave-ins in the tunnel roof. This occurred usually when approaching an altered zone where a charged aquifer meets the tunnel profile, such as at chainage $0+919 \mathrm{~km}$. Based on drilling reports and rock mass studies, the tunnel will pass through a poor-quality rock mass at chainage $3+250$ to $5+200 \mathrm{~km}$. In chainage $7+000$ to $8+600 \mathrm{~km}$, the potential of squeezing ground has been assessed in more detail because of the thickness of the overburden. Based on the method proposed for prediction of squeezing by Singh et al. (1992), it is believed that squeezing is not likely in this sub-section because $\mathrm{H}$ is less than $350 \mathrm{Q}^{1 / 3}$. The results from application of 
other evaluation and predicting techniques such as those described in references Muir Wood (1972), Sing and Goel (1999), Aydan et al. (1993), and Hoek and Marinos (2000) tend to confirm this finding.

\section{Unit C}

This section makes up the tunnel route in chainages $0+700$ to $0+919 \mathrm{~km}, 1+600$ to $2+250 \mathrm{~km}, 8+600$ to $9+100 \mathrm{~km}$ and $9+250$ to $9+900 \mathrm{~km}$. It is composed of green to grey coloured weathered and crushed schist. Chainage $0+700$ to $0+919 \mathrm{~km}$ has already been excavated using conventional tunnelling, a combination of mechanical drilling and drill-and-blast techniques. The rock mass was of very poor quality and many collapses occurred, but collapsed sections were recovered using grouting operation, installing heavier supports, and using an additional layer of dry mix shotcrete. Chainage $1+600$ to $2+250 \mathrm{~km}$ is surrounded by the two hidden valleys full of saturated fine-grained soils, as shown in Figure 7, and the quality of the rock mass is very poor. Because of the burial depth of the tunnel in chainages $8+600$ to $9+100 \mathrm{~km}$ and $9+250$ to $9+900 \mathrm{~km}$, a more detailed examination of the potential for squeezing ground in critical sections (i.e. deepest sections) within these chainages was undertaken. As shown in Table 3, some sections are likely to evidence mild to moderate squeezing condition.

\section{Unit D}

This GMU is composed of meta-dolomite and meta-quartzite with inter-beds of compact schist, which is the dominant rock type in chainage $5+200$ to $7+000 \mathrm{~km}, 11+500$ to $11+600 \mathrm{~km}$ and $11+800$ to $12+200 \mathrm{~km}$. These sections are composed of a good quality rock masses and therefore squeezing ground condition is not likely. However, a fault which intersects the tunnel route is identified at chainage $5+250 \mathrm{~km}$. The adverse effects of this fault on the tunnel such as increased seismic risk, deterioration of the rock mass quality (fault zone or crushed zone) and an increase in water inflow into the tunnel in the fault zone should be investigated more thoroughly.

\section{Unit E}

The QLT will be excavated in this unit in chainages $0+919$ to $1+600 \mathrm{~km}, 2+250$ to $3+250 \mathrm{~km}, 9+100$ to $9+250 \mathrm{~km}$ and 9+900 to $10+800 \mathrm{~km}$. Unit E is composed of fully-saturated alluvial materials such as GC and CL-ML materials of Quaternary age. Rock squeezing ground condition assessment is not applicable in this type of ground.

As shown here, some sections along the first $16 \mathrm{~km}$ of the QLT tunnel are prone to ground squeezing problems. As a result of the present study, it is highly recommended to take into account the effect of the squeezing ground condition on the selected tunnelling technique. However, a complete and comprehensive study on the effects of other geo-hazards on the selected tunnelling technique to restart the project is recommended in order to reduce the risk of squeezing ground.

Choosing a conventional tunnelling technique to restart the QLT project using mitigation measures such as pre-grouting will help to reduce the squeezing ground problem. If a mechanised tunnelling technique is selected then using a shielded machine (e.g. Earth Pressure Balance machine with a mixed cutter head) is recommended because such a machine has to work both in soft ground (e.g. section E) and hard ground. Drilling a pilot borehole $30-40 \mathrm{~m}$ ahead of the TBM to check the rock mass condition will help to assess the squeezing ground condition and perform required mitigation measures such as grouting and foam injection in order to pass successfully from the problem bearing sections. 
Table 3 Summary of calculations for determining squeezing ground potential along the QLT1

\begin{tabular}{|c|c|c|c|c|}
\hline \multirow[b]{2}{*}{ Chainage } & \multicolumn{3}{|c|}{ Squeezing Ground Prediction Method and the Parameters Used } & \multirow{2}{*}{$\begin{array}{l}\text { Squeezing } \\
\text { Potential }\end{array}$} \\
\hline & $\begin{array}{c}\text { Singh et al. } \\
\text { (1992) }\end{array}$ & Goel et al. (1995) & Aydin et al. (1993) & \\
\hline $08+600$ & $\begin{array}{l}\mathrm{Z}=180 \mathrm{~m} \\
\mathrm{Q}=5.75, \text { Sub. } \\
\text { in Eq. }(1): \\
\mathrm{H}=623 \mathrm{~m} \\
\mathrm{Z}<\mathrm{rH}\end{array}$ & $\begin{array}{l}\mathrm{Z}=180 \mathrm{~m}, \mathrm{~N}=\mathrm{Q}_{\mathrm{SRF}=1}=5.25 \\
\mathrm{ZB}=180 \times 5=900 \mathrm{~m}^{2}, \text { From Fig. } \\
\text { 2. for } \mathrm{HB}^{0.10}=211.43 \text { and } \\
\mathrm{N}=5.25 \text { we have non-squeezing } \\
\text { ground condition }\end{array}$ & $\begin{array}{l}\alpha=\sigma_{\mathrm{ci}} / \gamma \mathrm{H}= \\
11 / 23.5 \times 0.180= \\
2.60<2\end{array}$ & $\begin{array}{l}\text { Non- } \\
\text { squeezing } \\
\text { ground }\end{array}$ \\
\hline $09+100$ & $\begin{array}{l}\mathrm{Z}=185 \mathrm{~m}, \\
\mathrm{Q}=1.39, \text { Sub. } \\
\text { in Eq. }(1): \\
\mathrm{H}=390.56 \mathrm{~m}, \\
\mathrm{Z}<\mathrm{H}\end{array}$ & $\begin{array}{l}\mathrm{Z}=185 \mathrm{~m}, \mathrm{~N}=\mathrm{Q}_{\mathrm{SRF}=1}=1.38 \\
\mathrm{ZB}=185 \times 5=925 \mathrm{~m}^{2}, \text { From Fig. } \\
\text { 2. for } \mathrm{HB}^{0.10}=217.30 \text { and } \\
\mathrm{N}=1.38 \text { we have mild-squeezing } \\
\text { ground condition }\end{array}$ & $\begin{array}{l}\alpha=\sigma_{\mathrm{ci}} / \gamma \mathrm{H}= \\
11 / 23.5 \times 0.185= \\
2.52<2\end{array}$ & $\begin{array}{l}\text { Non- to mild- } \\
\text { squeezing } \\
\text { ground }\end{array}$ \\
\hline $09+900$ & $\begin{array}{l}\mathrm{Z}=200 \mathrm{~m}, \\
\mathrm{Q}=1.39, \text { Sub. } \\
\text { in Eq. }(1): \\
\mathrm{H}=390.56 \mathrm{~m}, \\
\mathrm{Z} \ll \mathrm{H}\end{array}$ & $\begin{array}{l}\mathrm{Z}=200 \mathrm{~m}, \mathrm{~N}=\mathrm{Q}_{\mathrm{SRF}=1}=1.38, \\
\mathrm{ZB}=200 \times 5=1,000 \mathrm{~m}^{2}, \text { From } \\
\text { Fig. } 2 . \text { for } \mathrm{HB}^{0.10}=234.92 \text { and } \\
\mathrm{N}=1.38 \text { we have a moderate- } \\
\text { squeezing ground condition }\end{array}$ & $\begin{array}{l}\alpha=\sigma_{\mathrm{ci}} / \gamma \mathrm{H}=5 / 24 \times 0.20 \\
=1.04<2\end{array}$ & $\begin{array}{l}\text { Non- to } \\
\text { moderate- } \\
\text { squeezing } \\
\text { ground }\end{array}$ \\
\hline
\end{tabular}

\section{Conclusions}

The first $16 \mathrm{~km}$ of the QLT tunnel, a portion of the Dez-Qomroud water conveyance project in Iran, will pass through very difficult ground conditions with a collection of geological problems ranging from flowing materials, squeezing ground, high water inflow and pressure, mixed-face conditions and crushed zones and faults zones. This makes the QLT tunnel one of the most difficult and challenging tunnel projects around the globe.

The first $16 \mathrm{~km}$ of the QLT tunnel is situated in the Sanandaj-Sirjan zone, the most tectonically active zone among the geological provinces of Iran. Based on results obtained from preliminary engineering geological studies, a drill-and-blast technique was adopted as the construction method of the tunnel, begun in 2000. A number of unpredicted geological conditions led to abandonment of the project until complementary engineering geological and geophysical investigations could be conducted to provide sufficient data to continue the project. According to the new study this part of the QLT will pass through highly diversified conditions from soft saturated ground to medium and hard rocks in its first $16 \mathrm{~km}$. Five distinct GMUs were identified along the first $16 \mathrm{~km}$ of the QLT route based on geological, structural and geomechanical criteria. Unit E is composed of fully saturated alluvial materials such as GC and CL-ML of Quaternary age. Unit A is dark green competent andesite to andesi-basalt. Unit B is a slightly weathered green to grey schist with interbeds of meta-dolomitic limestone. Unit $\mathrm{C}$ is green to grey weathered and crushed schist. Unit D is mostly meta-dolomite and meta-quartzite with inter-beds of compact schist.

In addition to engineering geological problems, contractual problems because of the changed geology caused six years delay in project reactivation. Over US\$40 million direct costs to the client in design and construction of the first $16 \mathrm{~km}$ of the QLT were lost. Construction of the first $16 \mathrm{~km}$ of the QLT project restarted in December 2007, redesigned with results obtained mainly from the current study reported in this article. These events are unfortunately a typical example of the importance in conducting comprehensive Engineering Geological investigations for such a large civil project. The assigned budget for these engineering geology activities should be at least three to five per cent of the primary value of the contract.

Each GMU identified along the first $16 \mathrm{~km}$ of the QLT axis was evaluated for squeezing ground condition. Also, some remedial measures have been recommended to mitigate the problem such as pre-grouting. Unit A is not susceptible to squeezing ground condition. The QLT will pass through Unit B in chainages $0+356$ to $0+700 \mathrm{~km}, 3+250$ to $5+200 \mathrm{~km}, 7+000$ to $8+600 \mathrm{~km}, 10+800$ to $11+500 \mathrm{~km}, 11+600$ to $11+800 \mathrm{~km}$ and 
$12+200$ to $16+000 \mathrm{~km}$ which are composed of a slightly weathered, green to grey schist with inter-beds of meta-dolomitic limestone. The chainage $7+000$ to $8+600 \mathrm{~km}$ has been assessed for the squeezing ground potential in more detail using different methods because of its notable depth. It was concluded that this chainage is not prone to squeezing ground condition. Unit $C$ in chainages $1+600$ to $2+250 \mathrm{~km}$ are delimited by two hidden valleys filled with saturated fine-grained soils. Also, some sections are prone to mild to moderate squeezing at chainages of $8+600$ to $9+100 \mathrm{~km}$ and $9+250$ to $9+900 \mathrm{~km}$. The squeezing ground condition is not likely in Unit D which is composed of meta-dolomite and meta-quartzite with inter-beds of compact schist, dominant rock type in chainage $5+200$ to $7+000 \mathrm{~km}, 11+500$ to $11+600 \mathrm{~km}$ and $11+800$ to $12+200 \mathrm{~km}$, because of its good rock mass quality.

Mitigation measures such as pre-grouting are recommended in case of adopting a conventional tunnelling technique to restart the QLT. A shielded TBM is recommended (e.g. Earth Pressure Balance machine with a mixed cutter head) in selection of mechanised tunnelling technique to restart the QLT project. Also, drilling a pilot borehole $30-40 \mathrm{~m}$ ahead of the TBM in order to check the rock mass condition, assess the squeezing ground condition and perform the required mitigation measures to pass successfully from the problem bearing sections is strongly recommended.

\section{Acknowledgements}

Ali Shafiei would like to thank his previous co-workers in the Dez-Qomroud project in Iran, especially H. Rahdar for his invaluable support and encouragement.

\section{References}

Aydan, O., Akagi, T. and Kawamoto, T. (1993) The squeezing potential of rock around tunnels: theory and prediction. Rock Mechanics and Rock Engineering, 2, pp. 137-163.

Aydan, O., Akagi, T. and Kawamoto, T. (1996) The squeezing potential of rock around tunnels: Theory and prediction with examples taken from Japan. Rock Mechanics and Rock Engineering, 29(3), pp. 125-143.

Barla, G. (1995) Squeezing rocks in tunnels. ISRM News Journal, 3/4, pp. 44-49.

Barla, G. (2001) Tunnelling under squeezing rock conditions. Tunnelling mechanics, In: Kolymbas (editor), Eurosummer-School in Tunnel Mechanics, Innsbruck, 2001, Logos Verlag, Berlin, pp. 169-268.

Barla, G. and Pelizza, S. (2000) TBM tunnelling in difficult ground conditions. In GeoEng2000 - An International Conference on Geotechnical and Geological Engineering, Melbourne, Australia, 20 p.

Barton, N.R., Lien, R. and Lunde, J. (1974) Engineering classification of rock masses for the design of tunnel support. Rock Mechanics, 6(4), pp. 189-239.

Bieniawski, Z.T. (1989) Engineering rock mass classifications. New York: Wiley.

Bieniawski, Z.T. (1976) Rock mass classification in rock engineering. In Exploration for rock engineering, proceedings of the symposium, Cape Town, Z.T. Bieniawski (editor), 1, pp. 97-106.

Dalgıc, S. (2002) Tunnelling in squeezing rock, the Bolu tunnel. Anatolian Motorway, Turkey, Engineering Geology, 67, pp. 73-96.

Deere, D.U., Hendron, A.J., Patton, F.D. and Cording, E.J. (1967) Design of surface and near surface construction in rock. Proceedings 8th US Symposium On: Failure and breakage of rock.

Farrokh, E., Mortazavi, A. and Shamsi, G. (2006) Evaluation of ground convergence and squeezing potential in the TBM driven Ghomroud tunnel project. Tunnelling and Underground Space Technology, pp. 504-510.

Goel, R.K., Jethwa, J.L. and Paithakan, A.G. (1995) Tunnelling through the young Himalayas - a case history of the Maneri-Uttarkashi power tunnel. Engineering Geology, 39, pp. 31-44.

Hoek, E. (2001) Big tunnels in bad rock. ASCE Journal of Geotechnical and Geo-environmental Engineering, Vol. 127(9), pp. 726-740.

Hoek, E. and Marinos, P. (2000) Predicting tunnel squeezing problems in weak heterogeneous rock masses. Tunnelling and Underground Space Technology, Part 1, pp. 45-51 and Part 2, pp. 33-36.

Hoek, E., Kaiser, P.K. and Bawden, W.F. (1995) Support of underground excavations in hard rock. Rotterdam: Balkema.

ISRM (1981) Suggested methods for rock characterization, testing and monitoring, ISRM commission on testing methods. E.T. Brown (editor) Oxford, Pergamon.

Kolymbas, D., Fellin, W. and Kirsch, A. (2006) Squeezing due to stress relaxation in foliated rock. International Journal for Numerical and Analytical Methods in Geomechanics, Vol. 30, pp. 1357-1367.

Kovari, K. and Staus, J. (1996) Basic considerations on tunnelling in squeezing ground. Rock Mechanics and Rock Engineering, 29(4), pp. 203-210.

Muir Wood, A.M. (1972) Tunnels for Road and Motorways. Quarterly Journal of Engineering Geology, 5, pp. 111-126. 
ÖNORM B 2203 (1994) Untertagebauarbeiten, Werkvertragnorm, Entwurf.

Palmstrøm, A. (1996a) Characterizing rock masses by the RMi for use in practical rock engineering, Part 1: The development of the Rock Mass index (RMi). Tunnelling and Underground Space Technology, 11(2), pp. $175-188$.

Palmstrøm, A. (1996b) Characterizing rock masses by the RMi for use in practical rock engineering, Part 2: Some practical applications of the rock mass index (RMi). Tunnelling and Underground Space Technology, 11(3), pp. 287-303.

Schubert, W. (1996) Dealing with squeezing conditions in Alpine tunnels. Rock Mechanics and Rock Engineering, 29(3), pp. 145-153.

Shafiei, A., Dusseault, M.B., Sani, F.F. and Sotoudeh, M. (2008) Qomroud long tunnel project in Iran: Rock mass characterization along the first $10.40 \mathrm{~km}$. Paper ARMA 2008-052, In 42nd US Rock Mechanics Symposium and 2nd U.S.-Canada Rock Mechanics Symposium, held in San Francisco, June 29-July 2.

Singh, B. and Goel, R.K. (1999) Rock mass classification - A practical approach in civil engineering. Elsevier Science Ltd., UK, 267 p.

Singh, B., Jethwa, J.L., Dube, A.K. and Singh, B. (1992) Correlation between observed support pressure and rock mass quality. Tunnelling and Underground Space Technology, 7, pp. 59-74.

Steiner, W. (1996) Tunnelling in squeezing rocks: case histories. Rock Mechanics and Rock Engineering, 29(4), pp. 211-246.

Stocklin, J. (1968) Structural history and tectonics of Iran: A review. AAPG Bulletin, 52, pp. 1229-1258.

Terzaghi, K. (1946) Rock defects and loads in tunnel supports. In rock tunnelling with steel supports, R.V. Proctor and T.L. White (editors), The Commercial Shearing and Stamping Company, Youngstown, Ohio, pp. 17-99.

Terzaghi, K. (1950) Geologic aspects of soft ground tunnelling. In Applied Sedimentation, Chapter 11, (editor) P.D. Trask, John Wiley and Sons.

Yassaghi, A. and Salari-Rad, H. (2005) Squeezing rock conditions at an igneous contact zone in the Taloun tunnels, Tehran-Shomal freeway, Iran: a case study, International Journal of Rock Mechanics and Mining Sciences, 42, pp. 95-108. 


\section{Nomenclature - Acronyms}

$\mathrm{d}=$ dry

GSI $=$ Geological Strength Index

$\mathrm{RMi}=$ Rock Mass index

$\mathrm{CL}=$ low plasticity clay

RMR = Rock Mass Rating

$\mathrm{RQD}=$ Rock Quality Designation

$\mathrm{S} \quad=$ saturated

$\mathrm{SRF}=$ Stress Reduction Factor (a parameter in Q)

$\mathrm{Z} \quad=\quad$ depth of the tunnel $(\mathrm{m})$

Symbols: Latin, then Greek

$\mathrm{C}=$ Cohesion $(\mathrm{kPa})$ for soils and $(\mathrm{MPa})$ for rock

$\mathrm{D} \quad=$ Tunnel diameter $(\mathrm{m})$

$\mathrm{E}=$ Young modulus in static state $(\mathrm{MPa})$

$\mathrm{E}=$ elasticity modulus in static state $(\mathrm{GPa})$

$\mathrm{V}_{\mathrm{p}}=$ primary wave velocity $(\mathrm{km} / \mathrm{s})$

$\mathrm{V}_{\mathrm{s}}=$ secondary wave velocity $(\mathrm{km} / \mathrm{s})$

$\mathrm{W}_{\mathrm{a}}=$ water absorption (\%)

$\rho \quad=\operatorname{density}\left(\mathrm{g} / \mathrm{cm}^{3}\right)$

$\sigma_{\mathrm{c}}=$ uniaxial compressive strength (MPa) for intact rock

$\sigma_{\mathrm{ci}}=$ uniaxial compressive strength of intact rock (MPa)

$\varphi=$ internal friction angle (degree) 